\title{
A CONCEPTUAL STUDY OF A CRANKTRAIN WITH LOW FRICTION LOSSES
}

\section{LUBOMÍR DRÁPAL, PAVEL NOVOTNÝ, ONDŘEJ MARŠÁLEK, PETER RAFFAI, VÁCLAV Pİ̌̌TĚK}

Institute of Automotive Engineering, Brno University of Technology, Technická 2, CZ61669 Brno, Czech Republic, Tel.: +420 541142264 , Fax: +420 541143 354, E-mail: drapal@fme.vutbr.cz

\section{SHRNUTí}

Tento článek popisuje výpočtový prístup pro ověření koncepční studie klikového mechanismu s nízkými třecími ztrátami a analysu jeho vibrací. Snižení třecích ztrát je dosaženo snižením počtu hlavních ložisek klikového hřídele, prričemž se sleduje torsní kmitání remenice klikového hř́dele a zatížení hlavních ložisek.

Výpočtový model zahrnuje modálně redukovaná pružná tělesa, hydrodynamická ložiska a je sestaven i numericky řešen v prostředí Multi-Body System.

\section{KLICČOVÁ SLOVA: KLIKOVÝ MECHANISMUS, TŘECI ZTRÁTY, HLAVNÍ LOŽISKA, MBS, TORSNÍ KMITÁNÍ}

\section{ABSTRACT}

This article presents computational approaches for verification of a conceptual study of a low-friction-loss cranktrain design and its vibration analysis. A decrease in friction losses is achieved by reduction of the number of crankshaft main bearings whilst the influence of a crankshaft pulley torsional vibration and main bearing loads are investigated.

The computational model is assembled and numerically solved in a Multi-Body System into which are incorporated modally reduced bodies, whilst the hydrodynamic aspect is also taken into account.

KEYWORDS: CRANKSHAFT, FRICTION LOSSES, MAIN BEARINGS, MBS, TORSIONAL VIBRATION

\section{INTRODUCTION}

A measure of engine design excellence is the overall engine efficiency. This parameter is defined as the product of several partial efficiencies, which are combustion efficiency, thermal efficiency, indicator diagram fill ratio, coefficient of cylinder charge exchange and mechanical efficiency. The mechanical efficiency is influenced by ventilation losses, friction losses and auxiliary power requirement, which are altogether known as mechanical losses. Friction losses are generated by component couples in relative motion, for example journal bearings, piston assemblies and cylinder liners, cam-tappet contacts etc.

Contemporary research shows that friction losses account for $20 \%$ of fuel consumption under the NEDC (New European Driving (ycle) and the potential for fuel savings can be up to 10\%. [1]

A decrease in fuel consumption due to reduction of friction losses can be achieved by changes to the material, geometry, surface treatment and design modifications of appropriate engine parts. One of the design modification methods rests in reduction of the number of crankshaft main bearings as they

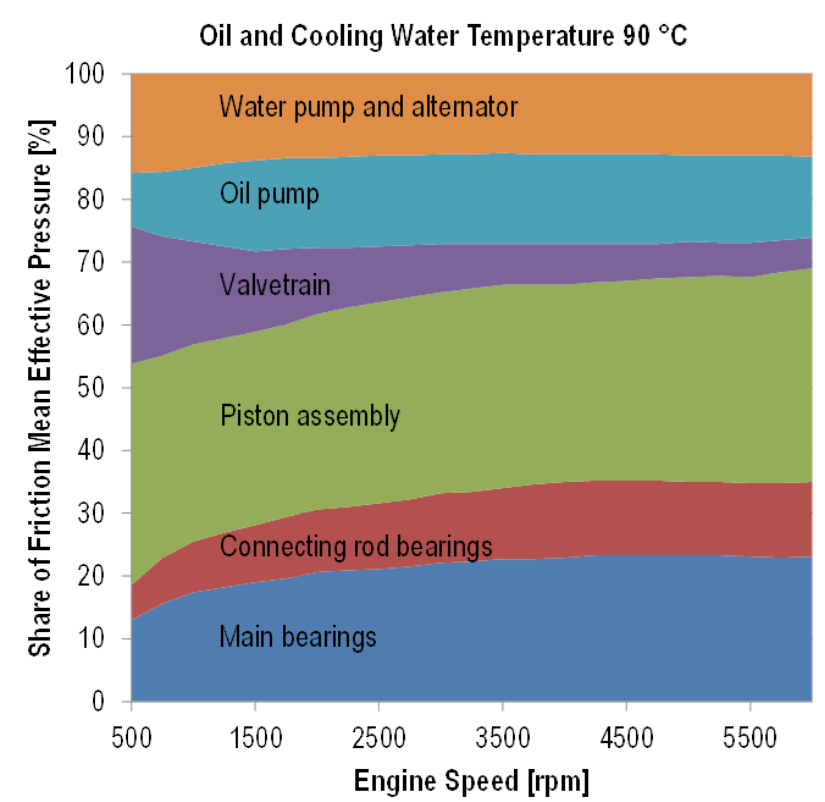

FIGURE 1: Friction losses sharing of a spark-ignition engine OBRÁZEK 1: Podíly třecích ztrát zážehového motoru 
account for a considerable proportion of engine friction losses, which is demonstrated by Figure 1 .

In the case of an in-line four-cylinder internal combustion engine, the changes are achieved by engine block and crankshaft modification in order to decrease the main bearing number from 5 to 3 .
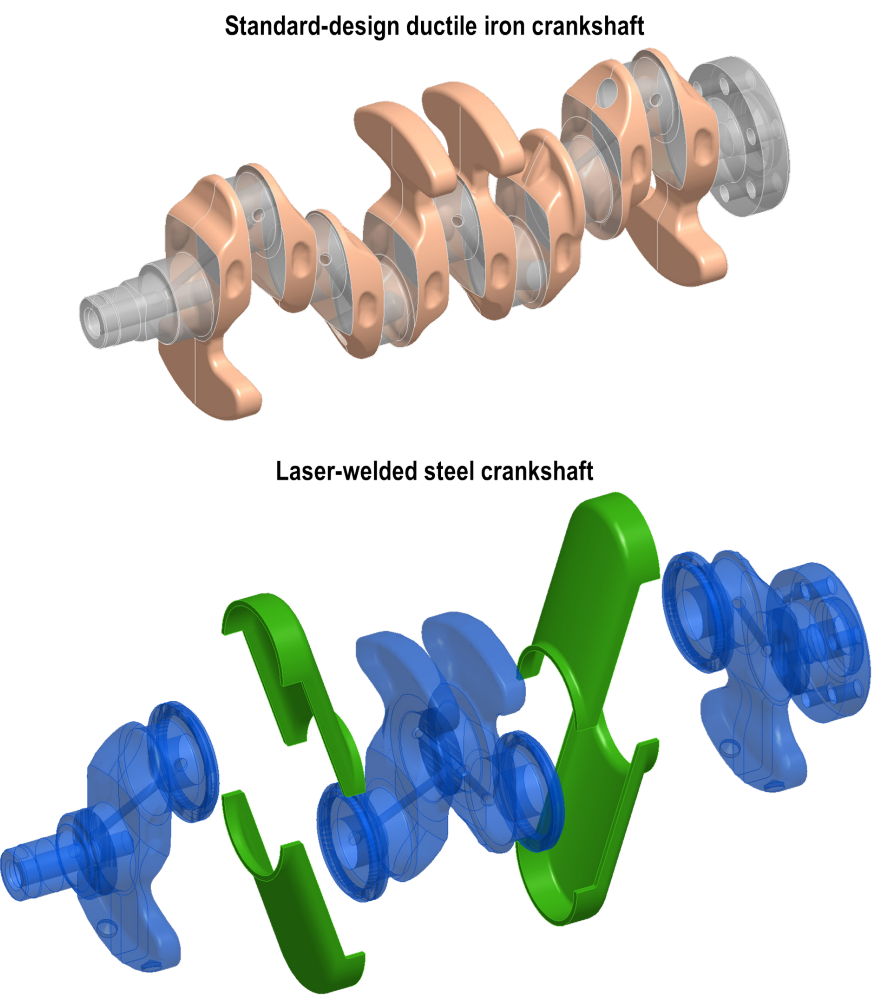

FIGURE 2: Designs of the standard and the welded crankshaft OBRÁZEK 2: Konstrukční řešení sériového a svařovaného klikového hřídele
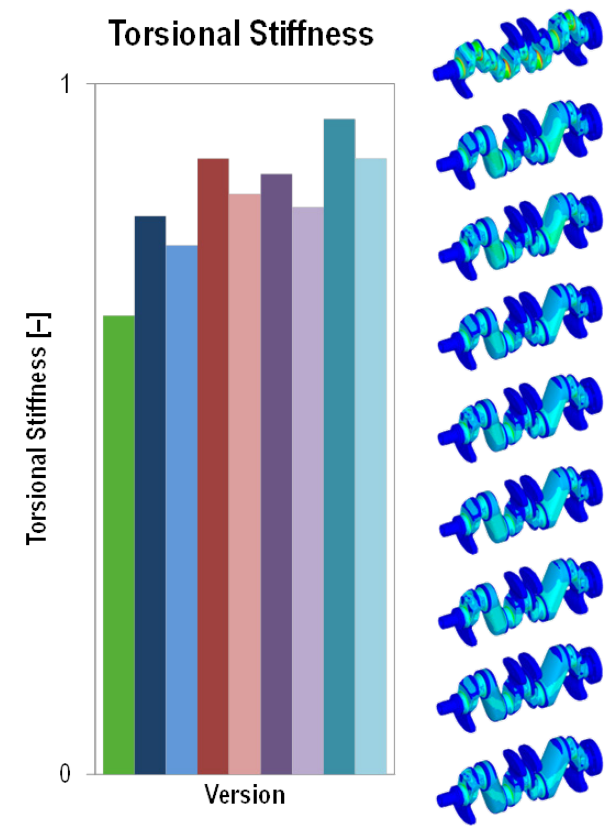

Standard design

S wism 3 - heavy

S wism 3 - lite

S wism 4 - heavy

S wism 4 - lite

T 3 - heavy

T3-lite

T 4 - heavy

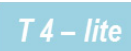

FIGURE 3: Torsional stiffness comparisons of all crankshaft versions OBRÁZEK 3: Porovnání torsní tuhosti všech variant klikových hřídelů

The mentioned modifications are implemented on a new naturally aspirated spark-ignition engine having 1.6 I displacement. Using state-of-the-art computational methods the influence on cranktrain dynamics and power losses is evaluated.

\section{CRANKSHAFT DESIGN}

The new 3-main-bearing crankshaft is based on a turbocharged version of the standard engine; therefore its main pins are slightly bigger. The missing main bearings are replaced by sheetmetal webs due to mass and inertia moments reduction. The connection between the web and the crankshaft is achieved using laser welding due to the low thermal load of the weld.

For practical reasons, a topology optimization of the design in not performed. However, eight variants of a 3-main-bearing crankshaft are proposed for comparison of inertial characteristics (weight and moment of inertia) and static (torsional and bending) and dynamic (modal shapes and their frequencies) stiffness with the standard one to obtain the best design with respect to the load of this important engine part. Some structural differences between variants consist of the sheet-metal design, the sheetmetal thickness and crankpin weight reduction.

\section{CRANKTRAIN DYNAMICS SIMULATION}

In order to investigate the dynamic response of an excited cranktrain, state-of-the-art computational approaches are employed.

A complex computational model of an engine (in other words a virtual engine) is solved in the time domain. This enables different physical problems, including various nonlinearities, to be incorporated. The virtual engine is compiled as well as numerically solved in MBS (Multi-Body System) ADAMS. ADAMS is a general code and enables integration of user-defined models to be made directly using ADAMS commands, user-written FORTRAN or $\mathrm{C}++$ subroutines. [2]

In general, the virtual engine includes all significant components necessary for dynamics analyses. The included module is a cranktrain, a valvetrain, a timing drive and a rubber damper. The following analyses deal just with the cranktrain as a main module of the virtual engine.

The cranktrain module consists of solid model bodies, linearly elastic model bodies and constraints between them.

Solid model bodies are:

- Piston assembly,

- Connecting rod assembly,

- Dynamometer rotor.

The linearly elastic model bodies are modally reduced Finite Element (FE) models suitable for dynamic simulation. These are:

- Crankshaft,

- Crankshaft pulley

- Flywheel, 
- Engine block,

- Cylinder head,

- Cranktrain sump,

- Gear case.

A dumbbell shaft connecting a flywheel with a dynamometer rotor is represented by a body with defined torsional stiffness and damping. These characteristics are adjusted on account of torsional vibration measurement.

The interaction between the crankshaft and the engine block is ensured via a non-linear hydrodynamic journal bearing model, where pre-calculated force databases obtained when solving a separate hydrodynamic problem are used.

The virtual engine is excited by means of cylinder pressure, defined by high-pressure measurement, and via inertial forces from moving parts. Simulation starts from $1000 \mathrm{rpm}$ and is continued up to $6000 \mathrm{rpm}$.

\section{RESULTS OF MULTI-BODY DYNAMICS SOLUTION}

\subsection{MAIN BEARING FRICTION LOSSES}

In general, calculation of friction losses of relatively low loaded powertrain slide bearings, such as main and crank pin bearings of a naturally aspirated engine, camshaft bearings and balancing shaft bearings, can neglect the elastic deformations. The solution is based on the Reynolds equation:

$\frac{\partial}{\partial x}\left(\frac{\rho h^{3}}{12 \eta} \frac{\partial p}{\partial x}\right)+\frac{\partial}{\partial y}\left(\frac{\rho h^{3}}{12 \eta} \frac{\partial p}{\partial y}\right)-U \frac{\partial(\rho h)}{\partial x}-\frac{\partial(\rho h)}{\partial t}=0$

where $x$ and $y$ are coordinates, $t$ is time, $h$ is oil film thickness, $\rho$ is oil density, $\eta$ is dynamic oil viscosity and $U$ is relative velocity. The relationship between oil viscosity and pressure can be expressed using Roeland's relation [6]:

$\eta(p)=\eta_{0}\left[\left(\ln \left(\eta_{0}\right)+9.67\right)\left(-1+\left(1+\frac{p}{p_{0}}\right)^{z}\right)\right]$

where $z$ is pressure-viscous index, the value is typically 0.6 . The value of pressure constant $p_{0}$ is $1.96 \cdot 10^{8} \mathrm{~Pa}$. The effect of pressure on oil density can be neglected easily too because the actual oil density $\rho$ is only 1.34 times higher $\left(\rho=1.34 \rho_{0}\right)$ for pressures approaching infinity $(p \rightarrow \infty)$.

The solution of a hydrodynamic problem requires reaction forces $\left(F_{x}\right.$ a $\left.F_{y}\right)$ and angular velocity $(\omega)$. These values are obtained from the virtual engine. Subsequently, the force equilibrium condition is solved:

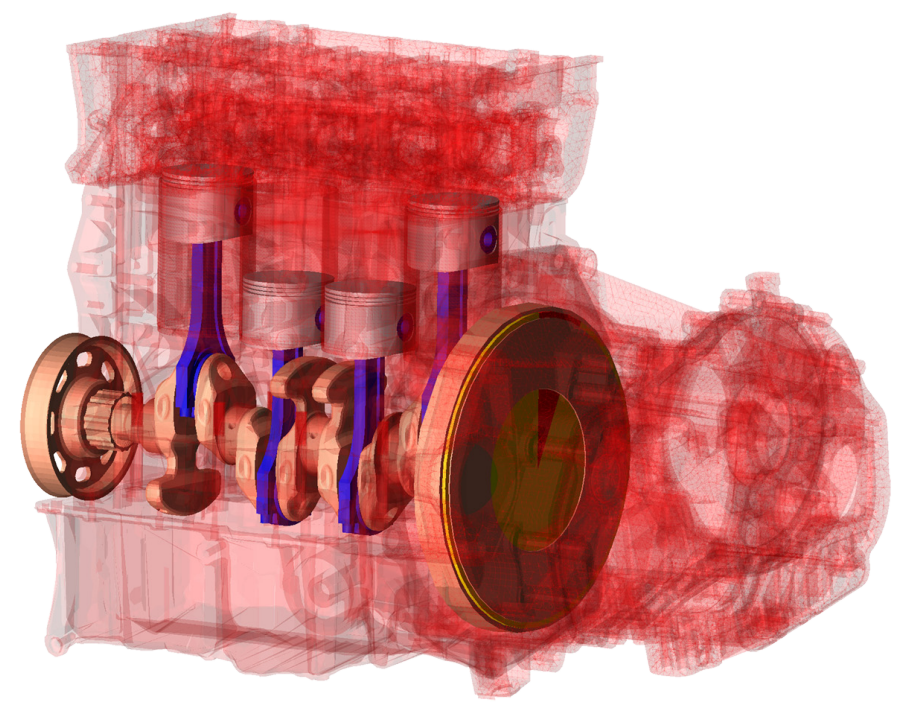

FIGURE 4: MBS model of the standard cranktrain design OBRÁZEK 4: MBS model sériového klikového mechanismu

$$
\left(\begin{array}{c}
f_{x} \\
f_{y}
\end{array}\right)=\mathrm{f}=\mathrm{F}_{\text {oUT }}+\mathrm{F}_{\text {IN }}(\varepsilon, \delta, \omega)=0,
$$

where $\mathrm{F}_{\text {OUT }}$ is a vector including outer forces $\left(F_{X}\right.$ and $\left.F_{Y}\right)$ obtained from the virtual engine, $\mathrm{F}_{\mathrm{IN}}$ is a vector including forces calculated from oil film pressures, $\varepsilon$ is relative eccentricity and $\delta$ is an angle of a minimum oil film gap compared with a coordinate system. Oil film forces in axes $x$ and $y$ can be calculated as [2]:

$$
F_{\text {OUT } X}=-\iint_{S} p \cos (\varphi-\delta) \mathrm{d} S=\int_{-B / 2}^{B / 2} \int_{0}^{2 \pi} p \cos (\varphi-\delta) R \mathrm{~d} \varphi \mathrm{d} y,
$$

$$
F_{\text {OUT } Y}=-\iint_{S} p \sin (\varphi-\delta) \mathrm{d} S=\int_{-B / 2}^{B / 2} \int_{0}^{2 \pi} p \sin (\varphi-\delta) R \mathrm{~d} \varphi \mathrm{d} y
$$

$B$ denotes the bearing width and $\varphi$ is an angular coordinate. The slide bearing model is realized in Matlab. The GaussSeidell method together with SOR (Successive Over-Relaxation) techniques are used to solve the hydrodynamic problem.

The aim of the force equilibrium condition is to determine input parameters $(\varepsilon$ and $\delta)$ minimizing the $\mathrm{f}$ function. In the case of a numeric solution, the f function has to be smaller than the chosen error. An iterative algorithm incorporates Newton's method and can be suggested as [2]:

$\left(\begin{array}{c}\varepsilon_{k+1} \\ \delta_{k+1}\end{array}\right)=\mathrm{q}_{k+1}=\mathrm{q}_{k}+\Delta \mathrm{q}_{k}$,

$\Delta \mathrm{q}_{k}=\mathrm{J}\left(\mathrm{q}_{k}\right)^{-1} \mathrm{f}\left(\mathrm{q}_{k}\right)$, 
where $\mathrm{q}_{k}$ is a vector of generalized coordinates in step $k_{1} \mathrm{~J}$ is a Jacobian, or a tangent matrix, and can be calculated as:

$$
\left.\mathrm{J}_{k}\right)=\left(\begin{array}{ll}
\frac{\partial f x}{\partial \varepsilon} & \frac{\partial f x}{\partial \delta} \\
\frac{\partial f y}{\partial \varepsilon} & \frac{\partial f y}{\partial \delta}
\end{array}\right)
$$

Jacobian (8) is solved numerically, where for every step $k$, the function $\mathrm{f}$ is evaluated in axes $x$ and $y$ [2]:

$$
f x\left(\varepsilon_{k}\right), \quad f y\left(\delta_{k}\right), \quad f x\left(\varepsilon_{k}+\Delta \varepsilon_{k}\right), \quad f y\left(\delta_{k}+\Delta \delta_{k}\right) .
$$

If the pressure distribution in the oil is known, the friction torque can be calculated as:

$$
M_{t}=R \iint_{S}\left(\frac{\eta \omega R}{h}-\frac{h}{2} \frac{\partial p}{\partial x}\right) \mathrm{d} S
$$

where $R$ denotes the bearing radius. [2]

Cranktrain main bearing power losses can be obtained as a sum of all main bearings if friction torque and instantaneous pin angular velocity are considered.

Analysis of main bearing power losses produces very interesting results concerning mechanical efficiency. Using just three main bearings for an in-line four-cylinder spark-ignition naturally aspirated engine leads to a reduction of power losses by approximately a third over the whole speed operating range, and even for the full and partial engine load compared to the standard cranktrain design (Figure 5).

\subsection{TORSIONAL VIBRATION}

Torsional vibration is common to internal-combustion engine crankshafts. The crankshaft mechanism generates alternating torque due to alternating combustion pressure in conjunction with the alternating effect of reciprocating mass inertias. This torque induces vibrations in the elastic crankshaft about the axis of rotation. The torsional vibration can cause cracking and crankshaft failure, and is therefore a very dangerous crankshaft loading.

The results obtained from harmonic analysis of the torsional vibration in the standard crankshaft variant are illustrated in Figure 6, which represents the crankshaft pulley angular displacement. It is clear that the sixth harmonic component of the torsional vibration, which achieves resonance at high speed, has a significant impact. At $4000 \mathrm{rpm}$ the resonance of the eighth harmonic component is evident. The tenth harmonic component also exhibits some resonance, but its impact on the total shaft oscillation is much smaller.

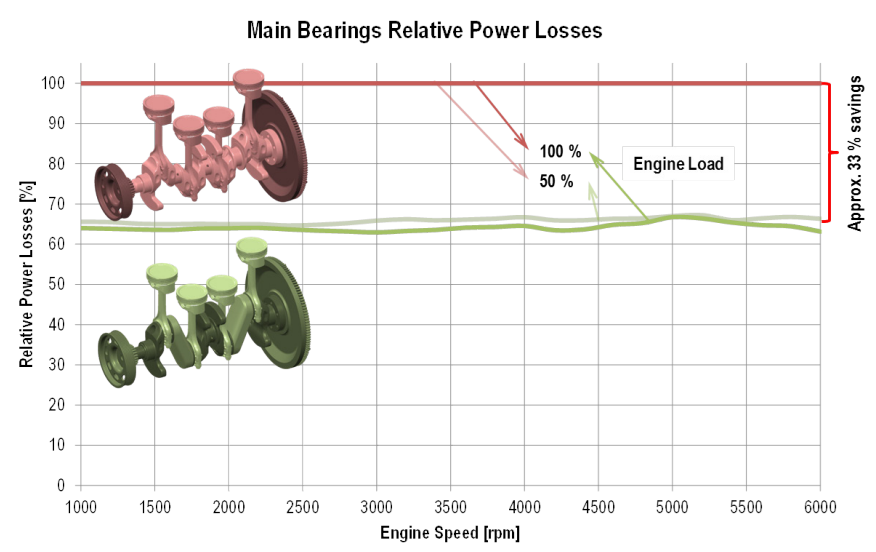

FIGURE 5: Main bearing relative power losses OBRÁZEK 5: Poměrný ztrátový výkon hlavních ložisek

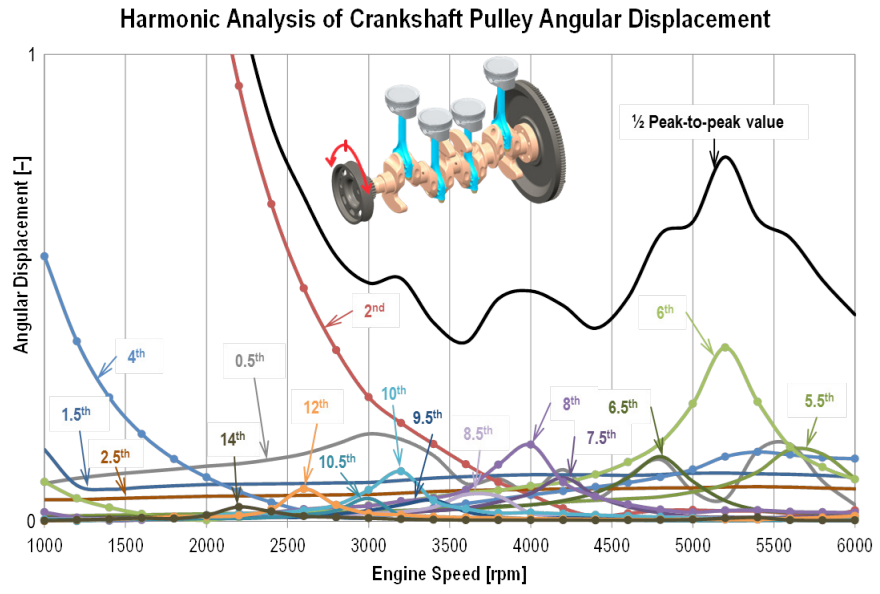

FIGURE 6: Harmonic analysis of the standard crankshaft pulley torsional vibration

OBRÁZEK 6: Harmonická analysa torsního kmitání řemenice sériového klikového hřídele

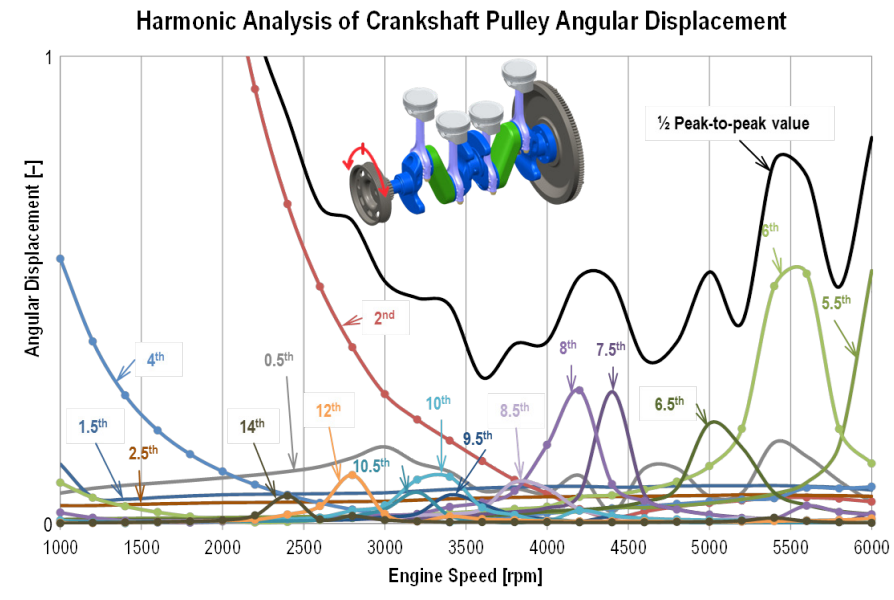

FIGURE 7: Harmonic analysis of the welded crankshaft pulley torsional vibration

OBRÁZEK 7: Harmonická analysa torsního kmitání řemenice svařovaného klikového hř́dele 
Harmonic analysis of the torsional vibration proved the theoretical assumptions, namely the fact that the major orders are most significant with respect to vibrations. For the given engine concept these orders are integer multiples of two. The synthesis is equal to the half the peak-to-peak value from the periodic torsional oscillation.

Figure 7 presents the results of the modified cranktrain harmonic analysis. Static stiffness analyses as well as the virtual engine simulation have proved that the 3-main-bearing crankshaft has greater torsional stiffness than the standard one. Higher torsional stiffness is evident, for example, in the resonance from the eighth harmonic component which occurs at $4200 \mathrm{rpm}$ (200 rpm higher compared to the standard one). Nevertheless, the small number of the crankshaft pivot points brings specific changes in cranktrain dynamics behaviour. The resonance amplitudes not only of the major harmonic orders, but also the other harmonic orders are increased. "The sharpness" of resonance curves is caused, in particular, by lower damping of cranktrain torsional vibration, since the dominant sources of damping are the crankshaft main bearings.

\subsection{MAIN BEARING LOAD}

Main bearing load can be obtained by a numeric integration of the bearing pressure field. The load is described by the resulting reaction force and moment. An important parameter of main bearing load is the maximum value of bearing reaction force for one engine operating cycle.

An analysis of the maximum values of main bearing reaction forces across the whole range of engine operating speeds is performed for the standard and the modified cranktrain (Figures 8 and 9). An increase of main bearing load is

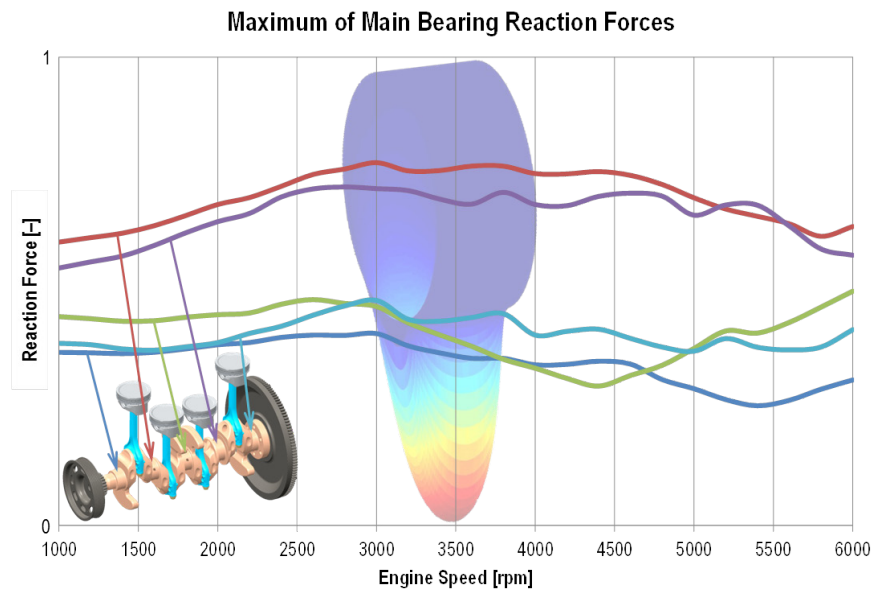

FIGURE 8: Maximum of main bearing reaction forces of the standard crankshaft

OBRÁZEK 8: Největší hodnoty reakčních sil hlavních ložisek sériového klikového hřídele detected for the 3-main-bearing crankshaft; however, it is not expected to be critical. Nevertheless, a new design of bearing shell should be considered.

Figure 8 also illustrates one peculiarity of an in-line four-cylinder spark-ignition internal combustion engine having a 5-mainbearing crankshaft where a specific shift in the middle main bearing load occurs. The shift is caused by the fact that the effect of the reciprocating part of inertial forces and their internal moments outweigh the load originated in indicated pressure acting on the pistons. At the standard full-loaded cranktrain, the shift occurs at approximately $4400 \mathrm{rpm}$ and the load of the middle main bearing is then escalated primarily by the inertia effect of reciprocating parts.

\section{CONCLUSION}

In general, the virtual engine results can help us to understand the dynamic behaviour of a new mechanically efficient powertrain and accelerate the development process together with reductions of expensive prototypes. Therefore, the computational tools based on FEM and MBS principles play an important role in modern powertrain research and development. The results of the dynamics analysis demonstrate the significant potential offered by crankshaft main bearing reduction for decreasing crankshaft power losses. If a naturally aspirated spark-ignition in-line four-cylinder engine is considered, power loss savings of around $33 \%$ are achievable in comparison with the standard configuration with a 5-main-bearing crankshaft. It should be noted that as the number of main bearings is reduced, so a greater torsional vibration of the cranktrain is excited. However, this effect can be successfully suppressed using a torsional damper the parameters and impact of which can also be verified using the virtual engine.

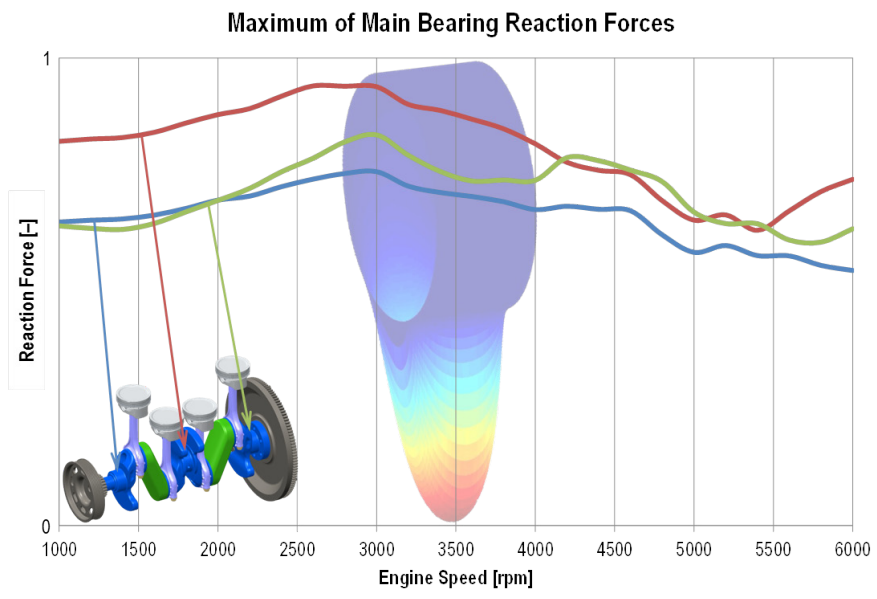

FIGURE 9: Maximum of main bearing reaction forces of the welded crankshaft

OBRÁZEK 9: Největší hodnoty reakčních sil hlavních ložisek svařovaného klikového hřídele 
The 3-main-bearing crankshaft concept seems to be an advanced way to increase the mechanical efficiency of a cranktrain. Therefore, it will be further evolved in terms of fatigue life computational prediction, detailed design modifications and subsequent prototype manufacturing.

\section{ACKNOWLEDGEMENT}

The presented work has been supported by European Regional Development Fund in the framework of the research project NETME Centre, project reg. no. CZ.1.05/2.1.00/01.0002, under the Operational Programme Research and Development for Innovation, and also by Technology Agency of the Czech Republic, project TE01020020 - Josef Bozek Competence Centre for Automotive Industry.

\section{LIST OF ABBREVIATIONS AND SYMBOLS}

\section{FEM Finite Elements Method \\ MBS Multi-Body System}

NEDC New European Driving Cycle

$S$ wism 3 (4) - heavy (lite)

"Simplified" version Without Inner Sheet-Metal having

3 (4) mm thickness of outer sheet-metal and without (with) crank pin lightening holes

SOR Successive Over-Relaxation

T 3 (4) - heavy (lite)

"Technological" version having 3 (4) mm thickness of outer sheet-metal and without (with) crank pin lightening holes

$B \quad$ Bearing width [m]

$\mathrm{f} \quad$ Vector of overall bearing forces [N]

$\mathrm{F}_{\text {IN }} \quad$ Vector including inner forces [N]

$\mathrm{F}_{\text {out }} \quad$ Vector including outer forces $[\mathrm{N}]$

$F_{x} \quad$ Reaction force in the direction of $x$ axis [N]

$f_{x} \quad$ Overall bearing force in the direction of $x$ axis [N]

$F_{y} \quad$ Reaction force in the direction of $y$ axis [N]

$f_{y} \quad$ Overall bearing force in the direction of $y$ axis [N]

$h \quad$ Oil film thickness [m]

J Jacobian (tangent matrix) [-]

$M_{t} \quad$ Friction torque [Nm]

$p \quad$ Pressure $[\mathrm{Pa}]$

$p_{0} \quad$ Pressure constant $[\mathrm{Pa}]$

$\mathrm{q}_{k} \quad$ Vector of generalized coordinates in step $k[-]$

$R \quad$ Bearing radius [m]

$S \quad$ Bearing surface $\left[\mathrm{m}^{2}\right]$

$t \quad$ Time [s]

$U \quad$ Relative velocity [ms $\left.{ }^{-1}\right]$

$x \quad$ Coordinate [m]

$y \quad$ Coordinate $[\mathrm{m}]$

$z \quad$ Pressure-viscous index [-]

\section{REFERENCES}

[1] MAASSEN, F. J., DOHMEN, J., PISCHINGER, S., SCHWADERLAPP, M. Engine Friction Reduction Design Measures for Reduction Fuel Consumption. MTZ Motorentechnische Zeitschrift Ausgabe. Wiesbaden: Springer Wieweg | Springer Fachmedien Weisbaden $\mathrm{GmbH}$, 7-8/2005, p. 30-33. ISSN 0024-8525 10814.

[2] NOVOTNÝ, P. Virtual Engine - A Tool for Powertrain Development, Inaugural Dissertation, Brno University of Technology, Czech republic, 2009.

[3] NOVOTNÝ P., PÍŠTĚK V. New Efficient Methods for Powertrain Vibration Analysis, Proceedings of the Institution of Mechanical Engineers, Part D, Journal of Automobile Engineering, 2010, pp. 611-629. ISSN 0954-4070.

[4] BUTENSCHÖN, H., J. Das hydrodynamische, zylindrische Gleitlager endlicher Breite unter instationärer Belastung. PhD dissertation, Universität Karlsruhe, Germany, 1976.

[5] REBBERT, M. Simulation der Kurbewellendynamik unter Berücksichtigung der hydrodynamischen Lagerung zur Lösung motorakusticher Fragen. Ph.D. dissertation, Rheinisch-Westfälischen Technischen Hochschule, Aachen, Germany, 2003.

[6] ROELANDS, C. J. A. Correlational Aspects of the ViscosityTemperature-Pressure Relationship of Lubricating Oils. Ph.D. Thesis. Delf: Technical University Delft, The Netherlands, 1966.

[7] CRAIG, R., R. Structural Dynamics. John Willey \& Sons, 1981. ISBN 0-471-04499-7. 